\title{
EFEITO DA PODA NA DOMINÂNCIA APICAL E FRUTIFICAÇÃO DE ABOBRINHA (Qucurbita moschata DUCHESNE) CV. PIRA MOITA
}

\author{
MARLI COSTA POLTRONIERI
}

Orientador: Prof. Dr. CYRO PAULINO DA COSTA

Dissertação apresentada à Escola Superior de Agricultura "Luiz de Queiroz", da Universidade de São Paulo, para obtenção do título de Mestre em Agronomia - Área de concentração: Genética $\theta$ Melhoramento de Plantas.

\footnotetext{
PIRACICAB A

Estado de São Paulo - Brașil Jülho - 1986
} 
. iii.

$\bar{A}$ memória

de meu pai Manoel Damasceno Costa

e de minha avó Aporonia Santos,

pelo incentivo aos estudos quando em vida,

Ofereço

À minha mae, Eunice Léa,

a meus, filhos Ericsson e Bruno,

a meu espôso, Luiz,

Aos meus irmãos,

pelo carinho

Dedico 


\section{AGRADECIMENTOS}

Expresso meu sincero agradecimento:

- Ao Prof.Dr. Cyro Paulino da Costa, pela segura e dedicada orientação, constante incentivo e acima de tudo pela amizade.

- A EMBRAPA, Empresa Brasileira de Pesquisa Agropecuäria, pela oportunidade de realização do curso.

- Aos funcionärios da Seqão de Hortaligas da ESALQ, Sr. Antonio Celza, Alcides Martins e Carlos Gilberto Santos pela colaboração na instalação e manutenção dos experimentos.

- À Mariana Zatarin, pelo apoio e amizade.

- $\bar{A}$ Rubenise Farias Gato, pelo auxílio prestado.

- Aos funcionários da Biblioteca do Departamento de Genética, pela amizade e dedicação.

- À Grafite, pelos serviços datilográficos, ätenção, e acima de tudo pela amizade. 
- Aos docentes do Departamento e Instituto de Genëtica da Esco Ia Superior de Agricultura "Luiz de Queiroz", pelos ensinamentos recebidos.

- A colega Ruth Rendeiro pelas correcões feitas. 
. $v$.

\section{$S U M A R I O$}

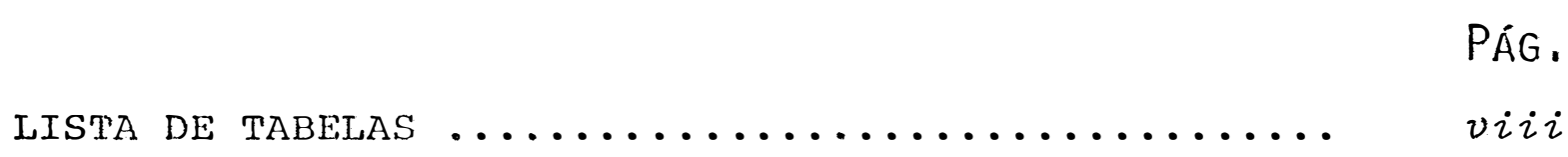

LISTA DE FIGURAS $\ldots \ldots \ldots \ldots \ldots \ldots \ldots \ldots \ldots \ldots \ldots \ldots \ldots \ldots \ldots \ldots$

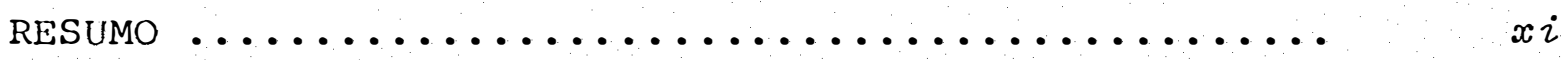

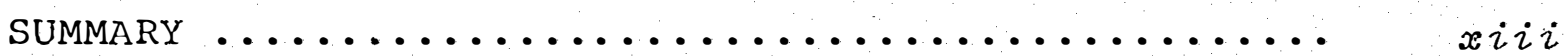

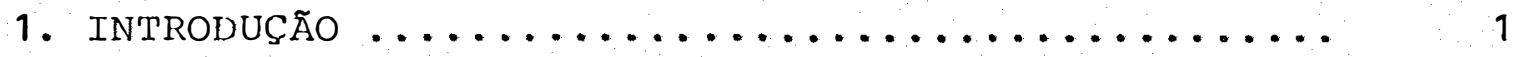

2. REVISÃO DE LITERATURA ....................... 4

2.1. Dominấncia apical ................. 6

2.2. A prática de poda na olericultura ......... 8

3. MATERIAL E METODOS .................... 15

3.1. Origem e característica da abobrinha cv. Pi-

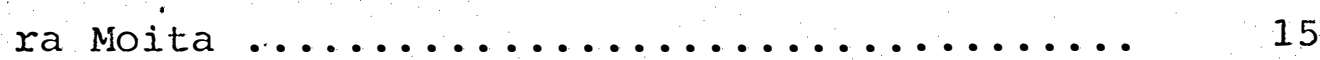

3.2. Condução do experimento............. 16

3.3. Delineamento experimental ............ 17

3.4. Obtenção dos dados experimentais ......... 18

3.4.1. Maturação - ciclo produtivo ........ 18

3.4.2. Etapas de colheita ............. 19

3.4.3. Produção de frutos por categoria de

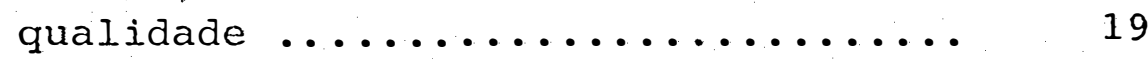

3.4.4. Ocorrência de frutificação em relação as ramificações ................. 20

3.4.5. Produção média de frutos por planta . 21

3.5. Anālise estatistica ................. 21 
4. RESULTADO E DISCUSSÃO $\ldots \ldots \ldots \ldots \ldots \ldots \ldots \ldots . \ldots \ldots 22$

4.1. Maturação e ciclo produtivo $\ldots \ldots \ldots \ldots \ldots . . \ldots \ldots$

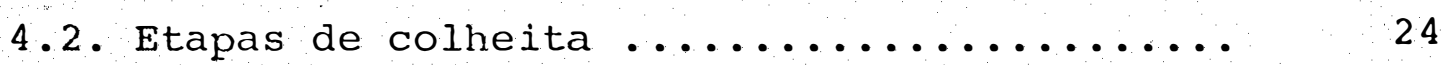

4.3. Produção de frutos por categoria de qualida

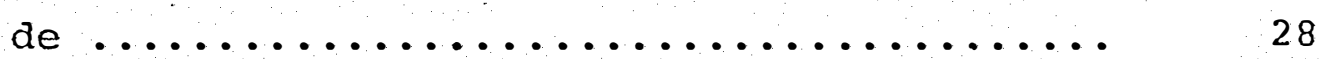

4.4. Ocorrência da frutificação em relação as ra mificações e manejo de poda ..............

4.5. Efeito da poda em relação ao número médio de fruto por planta ............... 34

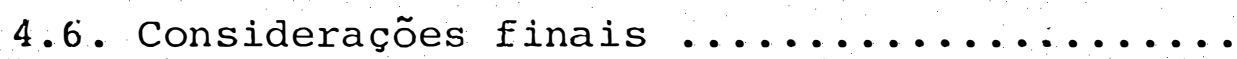

5. CONCLUSÃo $\ldots \ldots \ldots \ldots \ldots \ldots \ldots \ldots \ldots \ldots \ldots \ldots \ldots \ldots$

6. LITERATURA CITADA $\ldots \ldots \ldots \ldots \ldots \ldots \ldots \ldots \ldots \ldots, 40$

7. APENDICE $\ldots \ldots \ldots \ldots \ldots \ldots \ldots \ldots \ldots \ldots \ldots \ldots \ldots \ldots \ldots \ldots \ldots \ldots$ 


\section{LISTA DE TABELAS}

Tabela

Página

1

Média do número de dias do semeio a primeira e última colheita em relação ao manejo de poda em abobrinha cv. Pira Moita. Experimento 1, Piracicaba, SP, $1986 \ldots .$.

2 Média do número de dias do semeio a primeira e última colheita em relação ao ma-. nejo de poda em abobrinha cv. Pira Moita. Experimento 2, Piracicaba, SP, $1986 \ldots .$.

3 Efeito da poda nas etapas cquinzenais de colheita expressa pelónúmero médio total de frutos em parcela de 5 plantas. Experi mento 1, Piracicaba, SP, $1986 \ldots \ldots \ldots \ldots$

4 Efeito da poda nas etapas quinzenais de colheita, expressa pelo número médio total de frutos em parcelas de 5 plantas. Experimento 2, Piracicaba, SP, $1986 \ldots \ldots \ldots$.

5 Efeito do manejo da poda na abobrinha cv. Pira Moita em relação a frutificação expressa pelo número médio de frutos por parcela, dentro de cada categoria de qualidade e frutos. Experimento 1, Piracica-




- $i x$.

Tabela

Página

6 Efeito do manejo de poda na abobrinha $c v$. Pira Moita em relação a frutificação expressa pelo número médio de frutos por parcela, dentro de cada categoria de qualidade de frutos. Experimento 2 , Piracica

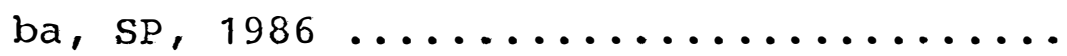

7 Efeito da poda sobre o numero médio de frutos por planta em abobrinha cv. Pira Moita. Piracicaba, SP. 1986........... 


\section{LISTA DE FIGURAS}

Representação gráfica da percentagem média de frutos, de acordo com sua ocorrência nas ramificações principal, primária, secundária e terciária em plantas de abobrinha cv. Pira Moita. Experimento I. Piracicaba, sP, $1986 . \ldots \ldots \ldots \ldots \ldots \ldots$

Representação gráfica da percentagem média de frutos de acordo com sua ocorrên cia nas ramificações principal, primária, secundária e terciária em plantas de abobrinha cV. Pira Moita. Experimento II. $\underline{\mathrm{P}}$

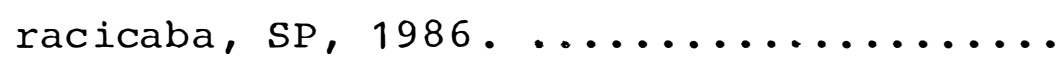


. $x i$.

EFEITO DA PODA NA DOMIMANACIA APICAL E FRUTIFICAÇ̃̃O DE ABOBRINHA (Cucurbita moschata DUCHESNE) cv. PIRA MOITA.

AUTOR: Marli Costa Poltronieri

ORIENTADOR: Prof.Dr. Cyro Paulino da Costa

\section{RESUPO}

A abobrinha cv. Pira Moita pertencente " espécie $C$. moschata Duchesne foi obtida a partir de um programa de retrocruzamento no qual transferiu-se o caráter moita da espécie $C$. pepo L. As plantas de C. moschata com sene braṛuítico. apresentam crescimento dās ramas prostadas e não erecta como em C. pepo. Assim, os internódios de abobxinha cv.Pira Moita, alongam-se de maneira negativa no período de chuvas com aparecimento de raízes adventícias e concentração acentuada de frutificação na rama principal com acentuada dominância apical .

Diante desses aspectos, o presente trabaIho teve como objetivo determinar o efeito da poda na dominância apical e na frutificação das ramificações primárias, secun dárias e terciárias da abobrinha cv. Pira Moita. 
. xii.

Foram realizados dois experimentos, utili zando-se o delineamento experimental de blocos ao acaso com seis tratamentos e cinco repetições.

O material utilizado constituiurse da mis tura de dez híbridos entre progênies $S_{1}$ da nopularão seleciona da para prateamento foliar da cv. Pira Moita.

Segundo os resultados obtidos, pode - se chegar as seguintes conclusões: os manejos da poda não influen ciaram a rnaturidade da abobrinha cv. Pira Moita, com um ciclo produtivo em 120 dias. Nas etapas de colheitas houve major con centração de frutos na terceira quinzena ou seja, com 45 dias. Não houve influência da poda na qualidade dos frutos. Houve es tímulo das ramificações laterais com a eliminação da dominância apical na rama principal. O manejo de poda có 69 ao 12 9 nó na rama principal influenciou a concentração na produção de frutos nas ramas laterais. Sem poda 40 à $50 \%$ da frutificação ocorre na rama principal, com poda principalmente a partir do 39 ao 12: nó da frutificação nos ramos laterais é da ordem de $80 \%$

A poda é benéfica e favorável na :abobrinha cv. Pira Moita devido ao seu efeito na compactação e equilíbrio de frutificação. 
. xiii.

PRUNIRG EFFECTS UPON APICAL DOMINANCE AND FRUIT SET IN SUMMER SQUASH (Cucurbita moschata DUSCH) cv. PIRA MOITA.

Marli Costa Poltronieri

- AUTHOR -

Prof.Dr.Cyro Paulino da Costa - ADVISER -

\section{SUMMiARY}

The summer squash cv. Pira Moita belonging to Cucurbita moschata specie, was got from a bactcross program in which, the bush charater of $C$. pepo was transfered. Plants of $C$. moschata with bush phenotype gene, show the prostated stem growth unlikely up righ as in $C$. pepo. The cv. Pira Moita sumer squash internodes, elongate negatively at the rainy season with adventicious roots and fruit set at the main stem with strong apical dominance.

\section{Considering these aspects, this papper} aimed to determine the pruning effects upon apical dominance and fruit set in the primary, secundary and terciary ramification stems in cv. Pira Moita summer squash. 
About two experiments were carried out, using random block experimental design, with six treatments anci five replications.

The material rias misture made of ten hybrids made among $S_{1}$ progenies from selected population of $\mathrm{Cv}$. Pira Moita, selected for silvery leaf character.

According with the results, conclusions could be drawn: as follow. The prune procedure did not influence the cv. Pira Moita summer squash maturity, with productive cycle, around 120 days. In the harvest steps there were higher fruit concentration after 45 days. The fruit quality was not affected by pruning.

The lateral stems were stimuleted with apical dominance elimination of the main stem. The pruning procedure of 6 th to 12 th. nodes of main stem affected the fruit concentration in the lateral stems. Without pruning, about 40 to $50 \%$ of fruit set occurs in the main stem, but with pruning from 3 rd to 12 th node, the fruit set in the lateral stem is around $80 \%$.

The prunning procedure is benefitial and favour the summer squash cv. Pira Moita, due to its influence in the plant compactation and equilibrium of fruit set. 


\section{INTRODUÇÃO}

O consumo de abóboras no Brasil é bastante popular e é feito com base na utilização de frutos maduros, imaturos e partes vegetativas. Quando o produto olerícola é consumido na forma imatura recebe o norne genérico de abobrinha. INos paises de clima temperado, a utilização de abobrinha é feita exclusivamente com o uso da espécie Cucurbita pepo. Suas cultivares caracterizam-se por serem de frutificação precoce a partir dos 40 dias com hábito de crescí mento moita e adaptadas ao curto ciclo de cultivo naquelas regiões. No Brasil existe uma preferência pela abobrinha $C$. pepo cv. Caserta, porém existem limitações no seu cultivo devida sua extrema susceptibilidade a determinadas doenças tais como oídio, mosaico e mildio. 
Ressalta-se no entanto, que no Brasil de maneira inédita existe a utilização de abobrinha com base no uso da espécie Cucurbita moschata utilizando-se a cultivar Menina Brasileira, que tem a vantagem sobre a Caserta por sua $\underline{\underline{r e}}$ sistência às doenças. No entanto trata-se de uma abóbora extre mamente tardia, com início de frutificação a partir de 75 dias. O hábito de crescimento rasteiro da cv. Menina Brasileira utilizado como abobrinha dificulta seu manejo fitotécnico principalmente no controle de ervas daninhas e no período de colheita. Entre as abóboras do gênero Cucurbita domesticadas,a Cucurbita moschata é a mais adaptada às condições de clima tro pical, não tolerando baixas temperaturas.

A cultivar Pira Moita (C. moschata) desti nada ao consumo de abobrinha, foi originalmente obtida em Pira cicaba - São Paulo, ESALQ. Originou-se através de um programa de retrocruzamento para o progenitor recorrente ..C. moschata cv. Menina Brasileira, a partir de uma população $F_{2}$ do cruzamento interespecífico de $C$. pepo x C. moschata (COSTA, 1974). A principal característica selecionada foi o häbito de crescimento meita. Após quatro retrocruzamentos foi selecionada em varias gerações para início de frutificação aos 60 dias e alta prolificidade.

O gene braquítico causa a redução dos internódios compactancio a planta de abóbora num hábito de crescí mento moita, pernitindo seu cultivo em fileiras bem como sua mecanização. Não afeta no entanto, as características reprodutivas e vegetativa da planta moita. O gene braquitico, porém 
em diferentes base genéticas de espécies de Cucurbita comporta -se de maneira diferente conforme seu uso como fruto maduro ou imaturo. As plantas de C. moschata com caráter moita apresentam crescimento das ramas prostadas e não erecta como na C. pepo. No período chuvoso a cv. Pira Moita tem uma tendência negativa de apresentar uma maior dominância apical na rama principal, e maior alongamento dos internódios em conseqüencia da emissão de raízes adventicias em contato com o solo úmido. Se comparada com a frutificação na Caserta, esta ocorre predominantemente na ramificação principal erecta com acentuada prolificidade, o que resulta em uma arquitetura mais compacta, e sem o:s problemas da Pira Moita.

Postula-se que com a prática da poda na ramificação principal da cv. Pira Moita, a dominância apical po deria ser transferida para ramificações primárias, secundárias e terciárias permitindo maior concentração de frutos e melhor arquitetura da planta.

O presente trabalho teve como objetivo determinar o efeito da poda na cominância apical em abobrinha cv. Pira Moita e seus consequentes efeitos na frutificação nas ramificações primárias, secundárias e terciāriás. 
.4 .

\section{REVISÃO DE LITERATURA}

Cucurbita pepo L. e Cucurbita moschata Duchesne, são espécies domesticadas de abóbora que tềm como centro de origem a região da América Central e México (ERWIN e HABER， 1929; WELLINGTON，1956; WHITAKER e DAVIS，1962; WHITAKER, 1965; ESQUINAS-ALCAZAR e GULICK, 1983).

Cucurbita moschata, a aboboreira rasteira, é constituída de plantas anuais rasteiras, de ramos sarmentosos, folhas grandes geralmente lobadas. E sensível à geada e não tolera temperaturas abaixo de $20^{\circ} \mathrm{C}$ (SARLI, 1958), quando isto ocorre inibe o desenvolvimento vegetativo e reprodutivo.

Seu produto olerícola pode ser classificado em duas categorias: abóboras sếcas que são consumidas a partir de frutos maduros e abobrinhas consumidas sob a forma imatura (MENDONÇA, 1963). 
Cucurbita moschasa cv. Menina Brasizeira caracteriza - se por ser uma planta rasteira e muito vigorosa. Os frutos quando novos, têm cor verde-claro, com estrias longitudinais mais escuras. No mercado é bem aceita como abobrinha, sendo o estágio ideal para colheita quando o fruto apresenta aproximadamente $25 \mathrm{~cm}$ de comprimento e $5 \mathrm{~cm}$ de diâmetro. A colheita para consu mo de frutos verdes, tem início cerca de 70 a 80 dias após o plantio e de frutos maduros entre 120 a 150 dias. A espécie Cu curbita pepo é constituída de plantas anuais, com folhas loba das e hábito de crescimento tipo moita, com tolerância às condições de temperaturas mais amenas (WHITAKER, 1962), sendo utị lizada principalmente como abobrinha. O hábito de crescimento moita é controlado pelo gene dominante $\mathrm{B} \mu$, que causa redução dos internódios, compactando a planta de abóbora (ESQUINAS-ALCAZAR e GULICK, 1983). Cucurbíta pepó cv. Caserta caracteriza -se por ser uma planta de crescimento tipo moita reigorosa, de folhas mosqueadas e limbo lobado. Os frutos são retos, de formato cilindrico, ligeiramente despontados do lado do pedúnculo, de coloração verde-clara, com estrias longitudinais mais escuras, devendo ser comercializado quando atingirem cerca de 20 $\mathrm{cm}$ de comprimento por 3,5 a $4,0 \mathrm{~cm}$ de diâmetro. A colheita in cia-se entre 45-50 dias após o plantio.

Sobre a herança do hábito moita, considerável estudo tem sido feito no gênero Cucurbita, pois este caráter é de grande importância econômica (ROBINSON et alii, 1976). Vários trabalhos citados por ROBINSON et alii (1976), mostram que o caráter moita em $C$. pepo é governado por um simples par de genes dominante. 
Possivelmente o caráter moita que ocorre em C. mäxima e C. pepo são alelos (DENNA e MUNGER, 1963).

A dominância do hábito moita no entanto é do tipo reversa (SHIFRISS, 1947), significando que os indivíduos heterozigotos mostram o caráter moita até o início da fru tificação, revertendo posteriormente para o crescimento raste $\underline{i}$ ro. Entretanto, DENA e MUNGER (1963), estabeleceram que o gene moita tem dominância incompleta em plantas adultas de $C$. pepo e recessivo em $C$. mäxima.

\subsection{Dominância apical}

A definição de dominância apical é relacionada com o efeito da predominância da gema terminal, suprimindo a brotação das gemas laterais (JANSCK, 1968).

A arquitetura de plantas depende das correlações de crescimento entre suas várias partes, sendo que o crescimento de ramos laterais está geralmente, sob o controle do ápice vegetativo (VALIO, 1979). Deste moda tanto o grau de ramificação quanto o estimulo do crescimento lateral e o desen volvimento do ramo principal, parecem ser função da dominância apical.

A diversidade da arquitetura de plantas superiores resulta de três fases de desenvolvimento e diferenciação dos ramos, segundo AUDUS (1959), citado por VALIO(1979): a. a iniciação dos primórdios das gemas; b. o desenvolvimento 
das gemas antes da fase de dormência; c. o crescimento dessas gemas. Esta última fase, geralmente conhecida como dominância apical, é determinada pela quantidade e o balanço de vários hormōnios, bern como, pelo estado nutricional dos tecidos.

Várias teorias procuram explicar a dominância apical. Atualmente, acredita-se no conceito de mobiliza cão ou translocação dirigida como controle do crescimento das gemas laterais. A auxina aplicada em caules decapitados, aumen ta fortemente a mobilização de nutrientes nesta região. A auxi na e outros hormōnios do ápice possivelmente causam uma translocação de nutrientes para essa região, em detrimento das gemas laterais, que ficam carentes de substrato para crescimento (VALIO, 1979).

Tem sido demonstrado que uma concentração elevada de auxina, movimentancio-se de cima para baixo no caule, impede a brotação das gemas laterais, mantendo-as em ustado de dormência (JANICK, 1968). A supressão do ápice vegetativo esti mula as gemas laterais, em geral, diretamente abaixo do corte.co mo consequência, o manejo e a prática de poda removendo a ponta da haste, pode resultar novas alterações de arquitetura pelo remanejamento da dominância apical em ramos laterais. "Por outro lado, a poda somente dos ramos laterais estimula o vigor do ramo principal e seu desemvolvimento, pela ação da au xina. FERRY e WARD (1959), mostraram que o efeito da ...remoção da gema apical é controlada pelo gradiente de auxina e sua coñ. 
centração na folha, frutos e caule. O nível de auxina do caule aumenta estimulada pelo crescimento dos frutos e produção de novas folhas.

\subsection{A prática de poda na olericultura}

Hā muito tempo o homem vem utilizando téc nicas de poda para modificar o crescimento das plantas visando aumento de produção e qualidade de frutos. A técnica conhecida como poda, influencia não só o crescimento, como também a arquitetura e o padrão de diferenciação de processos fisiológi cos como o florescimento e enraizamento.

A poda pode ser executada com vários propósitos, como por exemplo, o equilíbrio da carga de frutos nas espécies frutícolas perenes (JANICK, 1968). A alteração na arquitetura espacial ou das dimensões de uma planta, pode ter co mo objetivo melhorar sua aparência ou utilidade, podendo elevar a produtividade e a qualiclade de frutos. Esta técnica é uma prática usual em fruticultura, mas em relação a hortaliças existe certa controvérsia no seu uso.

CHANDLER (1923), apresentou dados que indicam ser a poda e a desfolhação prováveis responsáveis pela redução do crescimento da raiz, implicando em vários efeitos fisiológicos. 
Em plantas de tomateiro estaqueado efeito da poda na condução de duas hastes, produziram maior quantidade de frutos comerciáveis, por planta, maior precociaa de e rendimento por área (HAWTrioRN, 1939). Para TAMARO (1942), seria indispensável a desbrota do tomateiro com o objetivo de manter o equilíbrio de sua vegetação, evitando o desvio metabó lico e fisiológico da parte vegetativa em detrimento da frutificação; na cultura do pepino a poda é efetuada nos ramos laterais para estimular a dominância apical até a altura do estaqueamento. Posteriormente elimina-se a dominância apical da rama principal para estimular as ramificações laterais e conseqtientemente aumentar a produção do pepino no sistema es taqueado. Este mesmo autor sugere que a prática de desbrota em cultivo de abóbora pode favorecer a obtenção de frutos maiores e com maturação mais precoce.

A prática da poda na cultura do tomateiro é recomendada por LERENA (1945), como necessária para que a produção seja de melhor qualidade e rendimento.

Foi verificado por MURNEEK (1942) citado por KNOTT (1951), que a poda em tomateiro faz com que a gema logo abaixo do primeiro cacho seja estimulada a se desenvolver, ocorrendo entretanto efeitos negativos com esta prática, como por exemplo, a redução da produção total, aumento da precocida de e da podridão estilar dos frutos. 
A desbrota em tomateiro, segundo SARLI (1958), tem por objetivo fazer com que a planta desenvolva sobre uma ou duas hastes, de modo que os frutos fiquem mais expostos ao sol e arejamento' alcançando maior tamanho. Ressalva porēm, que as plantas desbrotadas produzem menos que as não submetidas a esta prática mas, que a produção de ambas pode-se equilibrar, se o período vegetativo for muito curto.

En estudo do efeito da poda em tomateiro, SOARES e KOLLER (1964), concluíram que a produção total é prejudicada por essa prática, enquanto que a produção de frutos do tipo especial é beneficiada.

Estudando tutoramento em tomateiro com e sem poda, ROCHA et alii (1964), verificaram que a produção, nú mero de frutos comerciáveis, bem como o peso médio dos frutos, foram superiores para o sistema de tutoramento em espaldeira e sem poda.

SOARES e KOLLER (1965), determinaram espe rimentalmente que o sistema de poda em tomateiro deixando quatro haste, foi supefior a testemunha não podada, expressa pelo número de írutos extras. Já ARAÚJO e NISIO (1974), concluíram que a desbrota em tomateiro estaqueado causou decréscimo nas produções.

. Com a prática da poda em tomateiro anão tipo salada, CHENG (1975) observou que houve redução na produção total e produção de frutos comerciáveis. No entanto, o pe- 
so médio e a porcentagem de frutos comerciáveis não foram influenciados.

Na cultura do pepino, FIlguerRA (1972), alega que produtores brasileiros argumentarn que a poda aumenta a precocidade, a produtividade e a qualidade do produto. Esta tese é compatível com os resultados obtidos por SIMS e GLEDHIL (1968), onde os autores constataram o efeito positivo na produ ção e qualidade dos frutos. Por outro lado, conflita com os resultados obtidos por PASSOS e VASCONCEIOS (1975), que ao compa rarem o efeito da poda dos ramos em pepino, concluíram não ser vantajoso.

A poda na cultura do pepino como prática comum, deve ser realizala no segundo nó, segundo PINTO (1977), para que favoreça o desenvolvimento dos frutos existentes nestas ramificações laterais, aumentando a porcentagem de frutos do tipo primeira e extra. Na cultura do pepino tutorado, a poda é feita na terceira ou quarta gema lateral, para favorecer inicialmente a rama principal. Posteriormente, elimina-se a ge ma apical para estimular a brotação lateral.

Na cultura da melancia, a poda é praticada por produtores de melancia japonesa, principalmente em são Paulo. Alguns experimentos demonstraram que há redução rıa produção total e que não compensa na produção e qualidade dos frú tos, (CASALI et alii 1982). 
PRADO (1960) comenta que, qualquer poda realizada na cultura da melancia, sómente acarreta desvantagens à produção, seja em peso, seja em número de frutos colhidos por área. Acrescenta ainda que também como o meloeiro, não há vantagem alguma na poda de seus ramos e que sua afirmativa é reforçada pelas conclusões obtidas em um ensaio feito em New Hampshire, com os seguintes tratamentos: A. sem poda; B. rama principal podada quando seus ramos laterais atingiram um metro de comprimento depois do primeiro ou segundo fruto; C. ramo principal podado a um metro de comprimento e ramos laterais não podados. Os pesos dos frutos das plantas podadas nos dois tratamentos foram os mesmos ou menores que o obtido em plantas não podadas.

BENOIT E CEUSTERMANS (1973) compararam OS efeitos da poda em melão pelo processo químico (Off-Shoot-T) e processo manual em plantações realizadas em três datas diferen tes no periodo de um mês. Nas duas primeiras épocas de plantio a poda química dos brotos ocasionou maior precocidade e maior produção do que os podados manualmente, porém, este processo produziu frutos maiores. No último plantio, as plantas podadas quimicamente tiveram menor produção, porém, os frutos foram maiores. Isto reforça a idéia de que existe uma época mais pró pria para se podar uma planta. 
De acordo com Lopez (1961), deve-se proce der a poda do broto terminal do meloeiro, quando a planta esti ver com as três folhas principais devidamente desenvolvidassen do esta prática indispensável para uma boa produção.

Relata BERNARDI (1974) que, nas cultivares européias de melão, certos agricultores adotam uma prática de condução da planta que consiste no seguinte: fazer a poda do ponteiro quando aparecem sete a nove folhas verdadeiras, dei xando crescer três ramos laterais, onde se processarão as frutificações.

Para comparar o efeito da poda em abóboras maduras (secas), LEAL e MENDONÇA (1973), utilizaram três tratamentos: a. poda das ramas no nono nó; b. poda no terceiro nó da rama principal e no sexto nó das ramas da segunda brotação; c. testemunha. Verificaram que os dois sistemas com poda empregados, acarretaram desvantagem à produção além do aumento da mão de obra na cultura; a testemunha respondeu com maior proāução e frutos de melhor peso médio.

\section{Experiências realizadas por FONTES et} a zii (1975) mostraram que, em moranga, a poda após o primeiro fruto apresentou 4\% a mais no número de frutos por planta que naquelas sem poda e podadas sómente após o segundo fruto; apre sentou também 4\% a mais no peso de frutos por planta quando comparadas com aquelas sem poda e 6\% a mais do que as podadas 
apôs o segundo fruto. Quanto à produção total, as plantas poda das após o primeiro fruto apresentaram 48 a mais do que as não podadas e $7 \%$ a mais do que aquelas podadas após o segundo fruto.

ARAOJO (1979), confirma os resultados obtidos por PRADO (1960) e afirma não haver vantagem alguma na poda dos ramos do meloeiro. 


\section{MATERIAL E MÉTODOS}

3.1. Origem e característica da abobrinha cv. Pira Moita

Cucurbita moschata cv. Pira Moita foi obtiäa no Departamento de Genética da ESALQ.

A partir de 1973 foi iniciado um trabalho de melhoramento, envolvendo uma população $\mathrm{F}_{2}$ do cruzamento inte respecifico 'Yankee Hybrid' (C. pepo) x 'Butternut' (C. moschata) em programa de retrocruzamento tendo como progenitor recor rente, a cv. 'Menina Brasileira'.

o objetivo foi incorporar na base genética

de C. moschata o caráter moita, de C. pepo (COSTA, 1974). Após quatro ciclos de retrocruzamento foi efetuado nove a dez ciclos de seleção massal para prolificidade e maturidade de frutificação aos sessenta dias. 
O material utilizado no experimento de po da, constituiu-se da mistura de dez de 3 hibridos entre progenies $S_{1}$ da população Pira Moita selecionada para prateamento fo liar. A cultivar Pira Moita é uma cultivar da espécie C. moscha ta com hábito de crescimento moita devido apresentar internódios curtos, possue maturação precoce, com inicio de frutificação aos 60 dias. Trata-se de uma cultivar altamente prolifica possuindo frutos de formato cilindrico similar aos frutos de Me nina Brasileira. Apresenta resistência ao mosaico da melancia,o idio e outras doenças de Cucurbitáceas equivalente a Menina Bra sileira. E recomendada para plantios na população de 5.000 plan tas por hectare, ou seja, em um espaçamento de $2 \mathrm{~m} \times 1 \mathrm{~m}$.

\subsection{Condução do experimento}

Os experimentos foram conduzidos em área do campo experimental do Instituto de Genética da ESAL@, Município de Piracicaba - São Paulo, a uma altitude de 576 metros, latitude de $22^{\circ} 42^{\prime}$ sul e longitude de $46^{\circ} 11^{\prime}$ oeste.

$$
\text { As semeaduras foram realizadas em } 10.08 \text {. }
$$

85 utilizando-se copinhos de papel para garantir a uniformidade de tamanho de mudas. O transplante para o campo definitivo deu-se à 23.08.85, utilizando-se duas mudas por cova no espaça mento 2,0 x 1,0 metros. Dez dias após o plantio definitivo, procedeu-se o desbaste deixando apenas uma planta por cova. 
No preparo das covas para o plantio foi aplicado $100 \mathrm{~g}$ de superfosfato triplo e 0,5 g de Furadan. Sessenta dias após o transplante foi feito uma adubação ern cobertura utilizando-se $100 \mathrm{~g}$ de sulfato de amônia por planta. Forarn efetuadas duas aplicações de Decis a $0,1 \%$ para o controle de brocas de frutos. Utilizou-se irrigação em sulco, a cada 5 dias.

\subsection{Delineamento experimental}

Forarn conduzidos simultaneamente dois experimentos utilizando-se para ambos o delineamento experimental de blocos ao acaso com seis tratamentos e cinco repetições. Os tratamentos foram os seguintes:

\section{Experimento I}

- $\mathrm{T}_{1}$ : Poda no 39 n̈ó da rama principal

$\mathrm{T}_{2}$ : Poda no 69 nó da rama principal

$\mathrm{T}_{3}:$ Sem poda (controle)

$\mathrm{T}_{4}$ : Poda no 99 nó da rama principal

$\mathrm{T}_{5}$ : Poda nas ramas laterais

T6: Poda no 129 nó da rama principal

Com exceção da testemunha, todos tratamen tos tiveram poda das ramas laterais, após estes atingirem apro ximadamente 1 metro de comprimento.

Experimento II

$\mathrm{T}_{1}$ : Poda no 3 ? nó da rama principal 
.18 .

$\mathrm{T}_{2}$ : Poda no 69 nó da rama principal

$\mathrm{T}_{\mathbf{3}}$ : Sem poda (controle)

$\mathrm{T}_{4}$ : Poda no 99 nó da rama principal

T5: Poda nas ramas laterais com $1 \mathrm{~m}$.

$\mathrm{T}_{6}$ : Poda no 129 nó da rama principal

Neste experimento, as ramas laterais não

foram podadas.

A parcela experimental foi constituida de $8 \mathrm{~m}^{2}$, com cinco plantas por área útil.

3.4. Obtenção dos dados experimentais

Nos experimentos foram avaliados os se-

guintes caracteres:

3.4.1. Maturação - ciclo produtivo

A maturação foi avaliada através do nứnero de dias da semeadura até a colheita dos primeiros frutos.

o ciclo produtivo foi estimado através do nụ̂mero de dias da semeadura até a ūltima colheita. 


\subsubsection{Etapas de colheitas}

Quanto as etapas de colheita, estas foram estimadas pelo número de frutos totais agrupados em cölheitas quinzenais. As colheitas dos frutos foram efetuadas a cada 2 a 3 dias.

3.4.3. Produção de frutos por categoria de qualidade

Correspondendo ao número de frutos classificados por categorias de qualidade expresso por escala de notas e critérios de julgamento.

o julgarnento de qualidade do fruto foi ba seado nos seguintes critérios: frutos de primeira, frutos de segunda e frutos de terceira, ou seja, considerados como refugo.

Na classificação dos frutos foram tomados como padrão para cada classe a média de 20 frutos para os caracteres de peso, comprimento; levando-se também em consideração a curvatura do fruto.

\begin{tabular}{|c|c|c|c|c|}
\hline $\begin{array}{l}\text { Escala de notas/ } \\
\text { qualidade de fruto }\end{array}$ & $\begin{array}{c}\text { Peso médio } \\
(g)\end{array}$ & $\begin{array}{l}\text { irento } \\
\text { fruto. }\end{array}$ & $\begin{array}{l}\text { médi } \\
(\mathrm{cm})\end{array}$ & Curvature do fruto \\
\hline 1 & $260-344$ & 23 & & Reto \\
\hline 2 & $300-346$ & 23 & & Levemente curvo \\
\hline 3 & $100-400$ & $<23 e$ & $e>23$ & Muito curvo \\
\hline
\end{tabular}


Considerou-se que os frutos com nota 1 e 2 são os de valor comercial e os de nota 3 sem valor .. comercial devido ao tamanho pequeno e ou fora do ponto comercial de colheita e ainda com curvatura acentuada do fruto.

3.4.4. Ocorrência de frutificação em relação às ramifi cações

Corresponde a percentagem de frutos localizados nas ramificações: principal, primária, secundária e terciária.

As ramificações da abōbrinha cv. Pira Moí ta foram classificadas em função do manejo de poda em:

Rama principal

Consiste na rama com dominância apical inicial, nos primeiros estádios do desenvolvimento da planta de abóbrinha.

Rama primária

Consiste nas ramas laterais originárias dos primeiros entrenós da rama principal, após a poda da gema apical da rama principal.

Rama secundária

Consiste nas ramas laterais originárias da rama primária em decorrência do manejo de poda. 


\section{Rama terciária}

São as ramificações originárias das ramas secundárias por efeito do manejo de poda.

3.4.5. Produção média de frutos por planta

Expresso pelo número médio de frutos obti dos em parcelas de 5 plantas para cada manejo de poda.

\subsection{Análise estatística}

Os dados obtidos foram analisados segundo o delineamento experimental de blocos ao acaso, sugerido por PIMENTEL GOMES (1978).

Na apresentação dos dados foram apresentados valores não transformados.

Na análise de variância para produção de frutos por planta e frutos classificados os dados foram transformados para $\sqrt{\mathrm{x}+0,5}$, conforme BARTLETT (1947).

Na comparação entre as médias utilizou-se

o teste de Tukey e Dunnett, indicado por steel e TORRIE (1960). 


\section{RESULTADO E DISCUSSÃO}

\subsection{Maturação e ciclo produtivo}

A maturação em relação ao manejo de poda em ambos experimentos apresentaram-se compatíveis, sem diferen ças entre eles, apresentando uma média de 65 dias para a colheita do primeiro fruto nos tratamentos de poda e 69 dias para a testemunha, Tabela 1 e 2. Assim sendo, observou-se que 0 manejo de poda não apresentou influência sobre a maturidade da abobrinha cv. Pira Moita, que é tida como intermediária 60 - 70 dias em relação a cv. Çaserta que é precoce com maturidade de 40 dias e a cv. Menina Brasileira que é tardia apresentando-se com maturidade de $75^{\circ}$ dias. 
Estimou-se através do número de dias do semeio à última colheita o ciclo das plantas em relação ao manejo da poda Tabela 1 e 2, obtendo-se uma média de 120 dias pá ra todos os tratamentos incluindo a testemunha, em ambos experimentos.

Tabela 1 - Média do número de dias do semeio à primeira e últi ma colheita em relação ao manejo de poda em abobrinha cv. Pira Moita. Experimento I, Piracicaba, SP, 1.986 .

Manejo de pöła

Média dé no de dias Méđiia de no de dias $\mathrm{p} /$ primeira collheita $\tilde{\mathrm{p}} / \mathrm{u}$ t.timaccolheita

Poda 3e nó da rama principal + Rama

lateral com $1 \mathrm{~m}$

65,4

121,4

Poãa 69 nó da rama principal + Rama

lateral" com $1 \mathrm{mi}$

65,8

120,2

Sem poda (testemunha)

69,8

120,2

Poda 99 nó da rama principal + Ramia

lateral com $1 \mathrm{~m}$

64,0

120,2

Poda soriente nas ramas laterais

64,4

118,2

Poōa 129 nó da rama principal + Rama

lateral com $1 \mathrm{mi}$

65,4

119,4 
Tabela 2 - Média do número de dias do semeio à primeira e últi ma colheita em relação ao manejo de poda em abobrinha cV. Pira Moita. Experimento II, Piracicaba, SP, 1986 .

Manejo de poda

Média de no de đias Média de no de dias 1a colheita

p/última colheita

Poda 3: nó da rama principal

64,4

120,6

Poda 69 nố da rama principal

64,4

118,2

Sem poda (testemunha)

69,8

117,4

Pođa yo nó da rama principal

63,0

119,0

Poda sónente nas ramas laterais

65,8

119,0

Poda 12\% nó da rama principal

65,4

117,4

\subsection{Etapas de colheitas}

Na avaliação da distribuição do nümero de frutos nas cinco etapas quinzenais de colheitas, observa-se pe los resultados apresentados nas Tabelas 3 e 4 , que tanto no ex perimento I como no II, para todos manejos de poda, incluindo a testemunha, que aproximadamente $80 \%$ da frutificação da abobrinha cv. Pira Moita concentrou-se nas três primeiras quin zenas da etapa de colheitas. Houve uma reação ao manejo de poda no 99 nó da gema apical da rama principal, no sentido de au mento e concentração de frutificação em relação aos outros tra 
tamentos, principalmente à testemunha não podada Tabela 7. A po da nos primeiros nós basais nãos mostraram aparentemente alguma diferença em relação à testemunha. Ressalta-se que a poda realí. zada nas gemas laterais, promoveu uma frutificação mais regular durante o período de 50 dias de colheita.

Fazendo comparação ao manejo de poda conduzido nosexperimentos I e II, ressalta-se que a poda no 99 nố da gema apical no ramo principal e nas ramas laterais (primá rias), com 1 metro, mostrou tendência de estímulo e maior prolificidade. Isso indica que na cultura de abobrinha cv. Pira Moi ta o manejo de poda tem que ser feito do 69 ao 129 nó e posteriormente um segundo manejo deve ser feito nas ramas laterais primárias quando atingirem aproximadamente $1 \mathrm{~m}$.

Os resultados mostram que a poda teve efeito positivo no aumento do potencial prolifico de frutifi cação, tornando a abobrinha cv. Pira Moita mais prolizica. Es se efeito pode ser explicado em decorrência da eliminação das gemas no 9 9 nó da rama principal, onde se verificou 'presença de flores fernininas nas ramificações primārias no primeiro e segundo nó. 


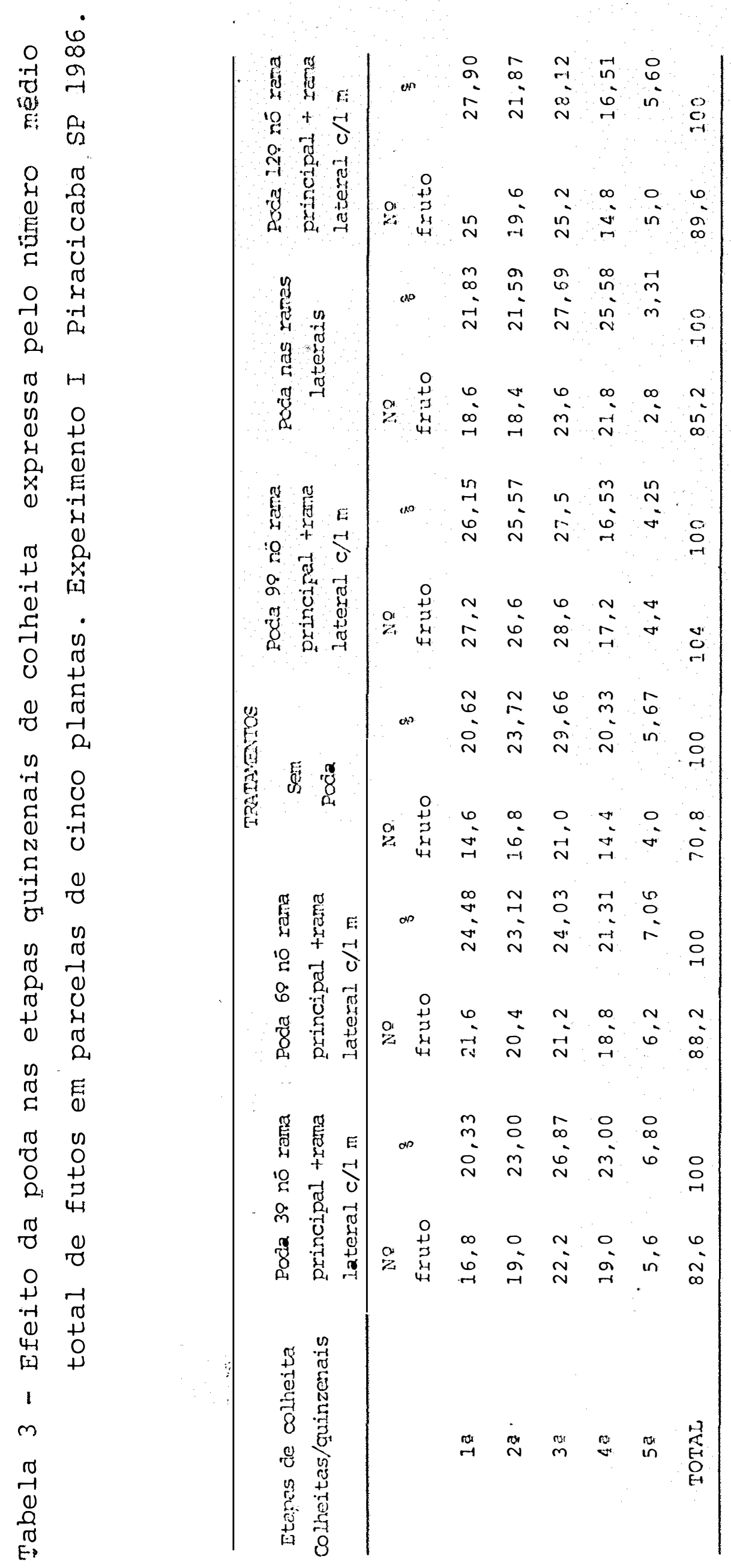




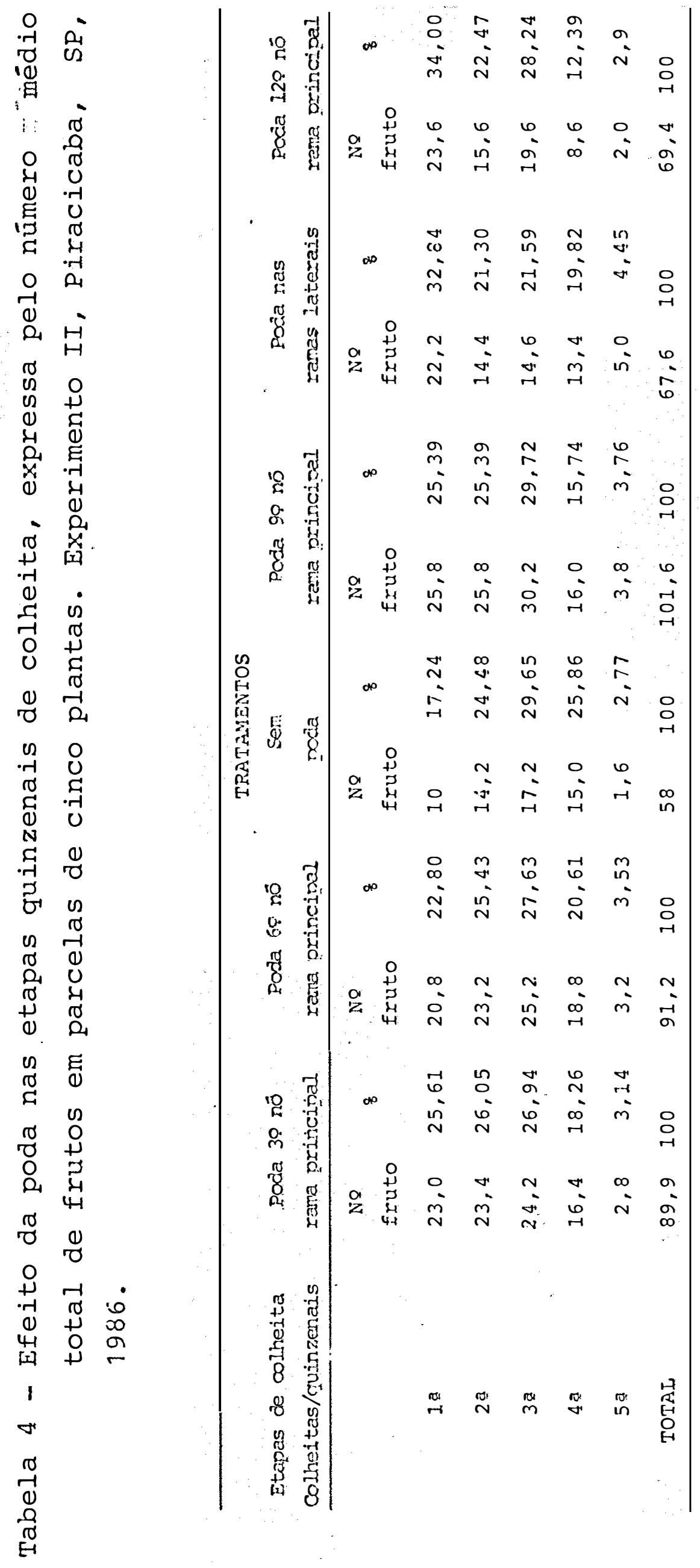




\subsection{Produção de frutos por categoria de qualidade}

Independente da poda à qualidade de frutos, mostrou um maior número de frutos do tipo $2 \mathrm{em}$ todos os tratamentos para os dois experimentos. Quanto à produção de frutos do tipo 1, o manejo de poda no 90 nó sobressaiu-se dos demais tanto no experimento I como no II.

A análise de variância (Tabela 1 do apêndice) não mostrou significância para os manejos de poda efetua dos no experimento I; O Teste de Tukey ao nível de 5\% mostrou que não houve contraste significativo entre as médias dos tratamentos, para todas as categorias de qualidade de frutos, Tabela 5 .

No experimento 2 , a análise de variância

detectou diferença significativa para os tratamentos tanto na produção de frutos do tipo 1 como do tipo 2 (Tabela 2 do apêndice), mostrando não significância para produção de frutos do tipo 3. Em relação a comparação entre médias, o Treste de Tukey mostrou que não houve diferença entre as médias dos tratamen tos para qualidade de frutos do tipo 1 e 3, (Tabela 6) mostran do no entantorpara produção de frutos do tipo 2, diferença entre as médias do manejo de poda no 99 nó para os manejos de po da no 3̣ nó e testemunha, não diferindo dos demais tratamentos.

$$
\text { O efeito da poda na abobrinha cv. Pira }
$$

Moita não altera a qualidade dos frutos, ou seja é neutra. 
A poda a partir do 99 nó tem um efeito significativo no aumento de frutos do tipo 2. A incidência de frutos refugos (tipo 3) foi inalterada para todos os tratamentos. Embora a análise estatística não tenha mostrado diferença entre os tratamentos, ressalta-se que o tratamento no 9o nó da rama principal mais lateral com $1 \mathrm{~m}$ obteve um ganho de 6 frutos por parcela em relação a testemunha, isto nos mostra que em condições de campo utilizando-se o espaçamento $2 \mathrm{~m}$ x lm, há um ganho de $\cong 30.000$ frutos, que é altamente significativo. Isto demonstra que apesar de não haver diferença significativa a poda é recomendada.

Tabela 5 - Efeito do manejo de poda na abobrinha cv. Pira Moita em relação a frutificação expressa pelo número médio de frutos por parcela, dentro de cada categoria de qualidade de frutos. Experimento I. Piracica ba, SP. 1986.

Escala de qualidade de fruto

Manejo de poda 1 2 3 (no médio de frutos por parcela)

Poda no 3o nó rama principal + Rama

lateral com $1 \mathrm{~m}$ 33,0 a 46,4 a 3,8 a

Pođa no 69 nó rama principal + Rarna

lateral com $1 \mathrm{~m}$

32,0 a

35,6 a

$8,6 \mathrm{a}$

Sem poda

27,2 a

36.6 a

6,2 a

Poda no 99 nó da rarra principal + Rania

lateral com $1 \mathrm{~m}$

38,2 a

56,4 a

6,4 a

Poda nas ramas laterais

35,4 a

54,6 a

4,6 a

Poāa no 12: nó da rama principal + Rama

lateral com $1 \mathrm{~m}$ 34,0 a 51,8 a 3,6 a CV. (잉 13,62 13,90 35,61

* Médias seguidas da mesma letra não diferem entre si pelo teste de Tukey à 5\% de probabiliàade.

** Parcelas constituídas de 5 plantas/área ūtil $\left(8 \mathrm{~m}^{2}\right)$. 
Tabela 6 - Efeito do manejo de poda na abobrinha cv. Pira Moita em relação a frutificação expressa pelo nümero médio de frutos por parcela, dentro de cada categoria de qualidade de frutos. Experimento II. Piracicaba, SP. 1986.

\begin{tabular}{|c|c|c|c|}
\hline \multirow{3}{*}{ Manejo de poda } & \multicolumn{3}{|c|}{ Escala de qualidade de fruto } \\
\hline & 1 & 2 & 3 \\
\hline & \multicolumn{3}{|c|}{ (no médio cie $f$} \\
\hline Poda no 39 nó rama principal & 27,0 a & 44,8 a & 2,6 a \\
\hline Poda no 6 : nó rama principal & 31,6 a & 33,2 a & 7,0 a \\
\hline Sem poda & 26,2 a & 32,6 a & 3,4 a \\
\hline Poäa no 9: nó rama principal & 37,8 a & 54,8 a & $6,2 \mathrm{a}$ \\
\hline Poda nas ramas laterais & 34,6 a & 51,3 a & 2,6 a \\
\hline Poda no 12 : nó rama principal & $31,6 \mathrm{a}$ & 48,8 a & 1,6 a \\
\hline $\mathrm{CV} .(\%)$ & 20,46 & 14,97 & 46,48 \\
\hline
\end{tabular}

* Miédias seguidas da mesma letra não diferem entre si pelo Teste de Tukey à 5\% de probabilidade.

** Parcelas constituídas àe 5 plantas/ārea útil $\left(8 \mathrm{~m}^{2}\right)$.

\subsection{Ocorxência da frutificação em relação às ramificaçōes e manejo de poda}

Os resultados de manejo de poda mostram claramente e graficamente uma distribuição ou uma ocor̉rência da frutificação nas diversas ordens de ramificações, Figura 1 e 2 . 
A abobrinha cv. Pira Moita quando não so-fre manejo de poda apresenta 40-50\% de sua frutificação ocorrendo sobre o ramo principal.

Com o manejo de poda a partir do 39 ao 129 nó a frutificação passa ocorrer de maneira concentrada no ramo primário e secundário em torno de $80 \%$; as ramas terciárias deram contribuição m.inima, em geral em torno de 10-17\%.Com base nos resultados demonstrados na Figura 1 e 2 torna-se evidente que o manejo de poda em abobrinha de hábito tipo moita como a cv. Pira Mojta, altera a frutificação nos ramos laterais. A poda eliminando a dominância apical do ramo principal. estimula as gemas laterais da ramificação primária sem afetar a prolificidade da cv. Pira Moita. O melhor efeito da poda con seqthentemente pode ser visto através da condução e compactação da planta sob o ponto de vista fitotécnico. Os dados mostram que nesse sentido a poda no $9 \varphi$ nó é que melhor distribui as frutificações nas ramificações laterais. 


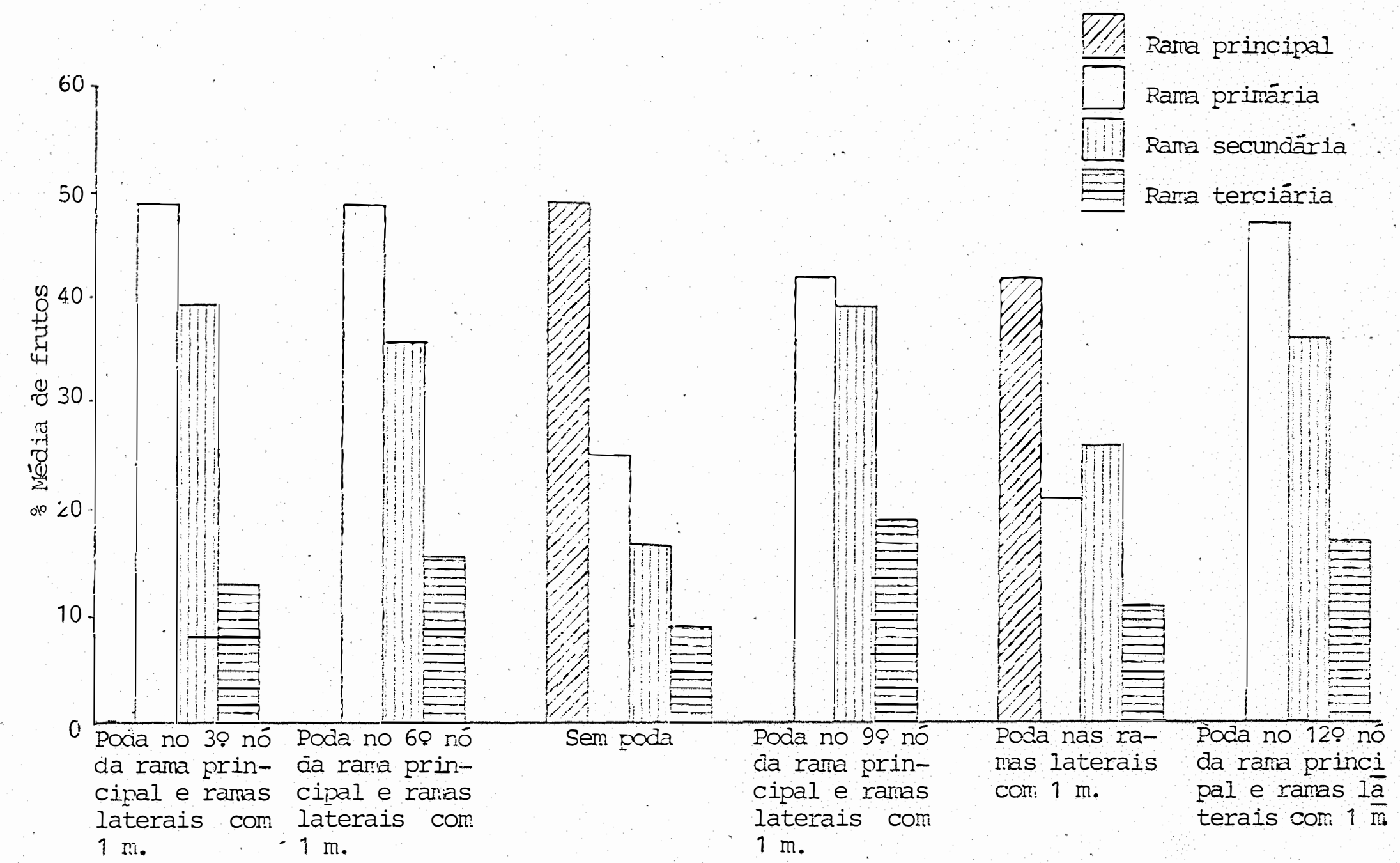

Figura 1 - Representação gráfica da percentagem média de frutos, de acordo com sua ocộ rência nas ramificacõos principal, primária, secundāria e terciária em pläntas de abobrinha cv. Pira Moita. Experimento I. Piracicaba, SP, 1986. 


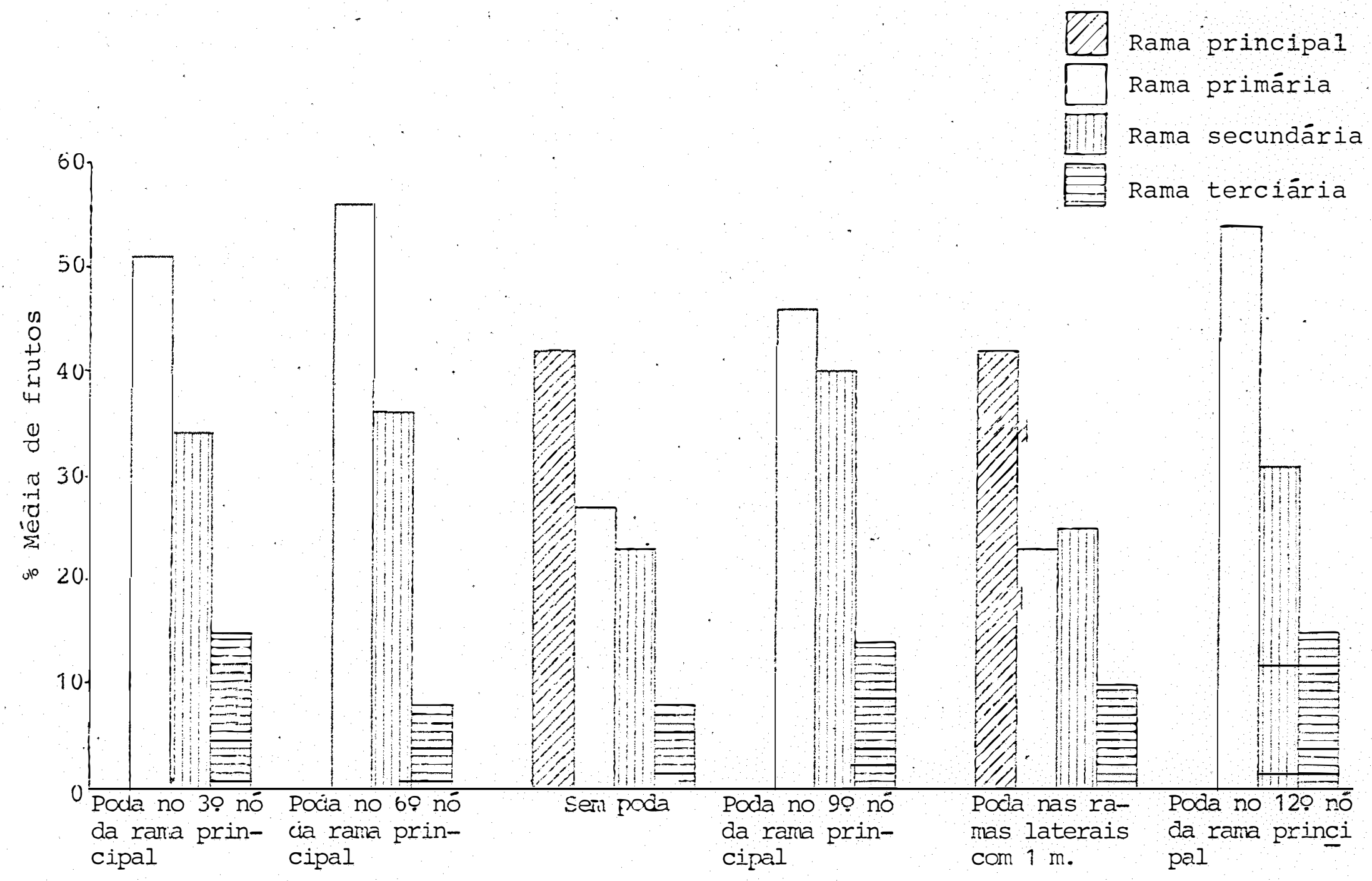

Figura 2 - Representação gráfica da percentagem média de frutos, de acordo com sua ocor rência nas ramificacoões principal, primária, secundária e terciária em plantas de abobrinha cV. Pira Moita. Experimento II. Piracicaba, SP, 1986. 
4.5. Efeito da poda em relação ao no médio de frutos por planta

A anālise de variância para o nümero médio de frutos por planta, no experimento I, apresentou para 0 teste $F$ urn valor não significativo, rnostrando não haver diferença entre os tratamentos, com relação a este caráter. Atravës do teste de Dunnett a nível de 5\% de probabilidade somente o tratamento de poda no 99 nó e rama lateral com 1 metro, mostrou-se significativo quando comparado à testemunha.

No experimento II, a análise de variância mostrou através do teste $F$ um valor significativo entre os tra tamentos, demonstrando que ao nível de 5\% de probabilidade pelo menos um contraste de médias difere de zero, havendo alguma diferença entre os manejos de poda efetuados. Comparando as mé dias dos tratamentos de poda com a testernunha, através do teste de Dunnett, verificou-se que o manejo de podas no 99 nó e no 39 nó foram significativos ao nível de 5\%.

o manejo de poda na abobrinha cv. Pịa Moita no 99 nó da rama principal, tanto no experimento I como no II; mostrou um efeito pronunciado en relação ao número médio de frutos por planta. 
Tabela 7 - Efeito da poda sob o número médio de frutos por planta em abobrinha cv. Pira Moita. Piracicaba - SP. 1986.

\begin{tabular}{|c|c|c|}
\hline Manejo de poda ${ }^{(a)}$ & Noxperimento I & $\begin{array}{l}\text { Experimento II } \\
\text { No médio de frutos }\end{array}$ \\
\hline Poda 38 nó rama principal & 16,52 & $15,76 *$ \\
\hline Poda 69 nó rama principal & 15,12 & 12,24 \\
\hline Sem poda & 14,00 & 13,36 \\
\hline Poda yọ nó rana principal & $21,52^{*}$ & $22,44 * *$ \\
\hline Poda nas ramas laterais & 18,92 & 15,64 \\
\hline Poảa 129 nó rama principal & 17,88 & 16,68 \\
\hline CV. $\frac{\circ}{0}$ & 11,01 & 13,56 \\
\hline
\end{tabular}

(a) No experimento I o manejo de poda foi efetuado na rama principal e na rama lateral com $1 \mathrm{~m}$.

* Méäias significativas ao nível de 5\% de probałilidade pelo teste de Dunnett emi relação ao controle (sem poda) .

** Médias muito significativa ao nível de 5\% de probabilidade pelo teste de Dunnett em relação ao controle (sem poła).

(b) Dados biológicos, não transformados.

(c) Médias de cinco repetições.

\subsection{Considerações finais}

A abobrinha $c v$. Pira Moita pertencente à espécie C. moschata foi obtida a partir de um programa de retrocruzamento o qual se transferiu o caráter moita da espécie C. pepo. O efeito fenotípico de compactação da planta de abóbo- 
ra na espécie $c$. pepo comparada com a base genética da espécie C. moschata manifesta-se de maneira diferente.

A C. pepo caracteriza-se por possuir ramas grossas e crescimento erecto com alta prolificidadelexpres são monóica), ocorrendo principalmente na rama principal associado com a precocidade na qual a frutificação ocorre com 40 dias. Por outro lado, a C. moschata caracteriza-se por ramos sarmentosos que normalmente crescem de maneira prostado com tendência à formação de raízes adventícias que em condições de maior pluviosidade e umidade no solo, tendem a alterar o gene braquítico com o alongamento dos ramos nos entrenós; Portanto - fenótipo Moita na base genética $C$. pepo age de modo diferente coImsarado com $C$. moschata.

Como a abobrinha cv. Pira Moita inicia sua frutificação aos 60 dias e tem hábito prostado, há uma ten dência da frutificação ocorrer na rama principal não afetando sua prolificidade, afetando porém, a arquitetura da planta.

A adoção da prática da poda para eliminar a domināncia apical do ramo principal numa primeira etapa, es-timula e transfere a mesma para as ramificações laterais, fazendo o remanejamento da frutificação e seu equilíbrio nos diversos ramos laterais.

A principal vantagem da poda é que não há efeito adverso na prolificidade, mas proporciona como maior benefício, a compactação da planta e uma tendência de melhorar a 
distribuição da frutificação nos ramos laterais primários e se cundários. Como a cultura da abobrinha implica em colheitas múltiplas de frutos imaturos a cada dez dias após a poliniza ção, essa concentração da frutificação nos 50 dias de colheitas não concorre entre si e não esuressa a planta com relação à frutificação subseqthente.

Uma das desvantagens da poda é o aumento da mão-de-obra e a possibilidade de transmissão de vírus mecanicamente. O custo talvez não seja tão crítico quanto na cultu ra de pepino; em relação à virose, a cv. Pira Moita é resistente ao virus da melancia raça 1 . 


\section{CORCLUSÃO}

Os resultados obtidos permitem as seguin-

tes conclusões:

a. Os manejos de poda não afetarar a maturidade da abobrinha cv. Pira Moita, que é tida como intermediária, a partir de 60 dias.

b. O ciclo reprodutivo ficou estabelecido em 120 dias aproxima damente para todos os tratamentos de poda.

c. Existe uma concentração na produção de frutos até 45 dias de etapas de colheitas, ocorrendo posteriormente urn decréscimo na produção. 
d. A poda da gema apical na rama principal eliminou a dominância apical, estirnulando as ramificações laterais sem afetar a prolificidade da abobrinha cv. Pira Moita.

e. Cerca de $80 \%$ da produção de frutos ocorre nas ramas laterais quando se efetua principalmente o procedimento de poda do 69 ao 129 nó.

f. A poda não teve efeito negativo na qualidade dos frutos em relação a testemunha não podada.

9." A poda no yo nó da rama principal com e sem pocá nas ramas laterais, teve seu efeito pronunciado através do número médio de frutos por planta. 


\section{Literatura CITADA}

ARAŨJO, L.M. \& J. NISSIO. 1974. Efeito da desbrota na produção do tomateiro (Lycopersicon eeculentum L.). Pesq. Agropec. Bras. 9:61-63.

ARAUJO, J.P. de. 1979. O número de ramos e de frutos por planta e sua influência no tamanho dos frutos do meloeiro (Cucumis melo L. cv. Valenciano). Piracicaba, ESALQ/USP, 63 p. (Dissertação de Mestrado).

BARTLETT, M.S. 1947. The uses of transformations. Biometrics. $3: 39-52$. 
BENOIT, F. e N. CEUSTERMANS, 1973. Chemical shoot thinning of melons under plastic tunnels. Hort. Abstr. 44:34.

CASALI, V.W.D.; P.E. SONNEMBERG \& J.F. PEDROSA; 1982. Melancia: cultivares e métodos culturais. Informe Agropecuário. 8:29-32.

CHANDLER, W.H., 1923. Results of some experiments in pruning fruit trees. Agr. Expt. Sta Bul. 415. 75 p.

CHENG, S.S., 1975. Efeito da poda na produção de tomateiro anão tipo salada, cultivar "kiko". Revista de olericultura. $15: 105-107$.

COSTA, C.P., 1974. Obtenção de abobrinha menina brasileira (Cucurbita moschata) com häbito de crescimento tipo moita e com tolerância ao mosaico da melancia. Rel. Cient. do I. de Genética. Piracicaba, 8:61-62.

DENNA, D.W. \& H.W. MUNGER, 1963. Morfology of the bush and vine habits and the allelism of the bush genes in Cucurbita maxima and Cucurbita pepo squash. Proc. Amer. Soc. for Hort. Sci. 82:370-377. 
ERWIN, A.T. \& E.S. HABER, 1929. Species and varital crossen. In: Cucurbits. Yowa. Agricultural Experiment Station, $263 \mathrm{p}$

ESQUINAS-ALCAZAR, J.T. \& P.J. GULICK, 1983. Genetic resources of cucurbitaceae. Rome. $101 \mathrm{p}$.

FERRY, J.F. \& H.S. WARD, 1959. Fundamentals of Plant Physiology. New York. The Mac Millan Co. Inc. 288 p.

FILGUEIRA, F.A.R. 1972. Manual de olericultura. São Paulo, Editora Ceres, $451 \mathrm{p}$.

FONTES, P.C.R., J.A. de MENEZES SOBRINHO \& R. MARINATO, 1965. Efeito do espaçamento, da poda e da condução das rimas sobre a produção da moranga. Revista de olericultura. SoB. Botucatu, 15:61-63.

HAiTHORN, L.R., 1939. Pruning unstaked tomatoes. Proc. Am. Soc. for Hort. Sci. 37:30-34.

JANICK, J., 1968. A ciência da horticultura. "São Paulo, Livraria Freitas Bastos. 485 p. 
KNOTT, J.E., 1951. Palestras sobre horticultura. Edição da Universidade de São Paulo. Departamento de Genética, 32 p.

LEAL, N.R. \& C.A. MENDONÇA, 1973. Influência da poda na produção da aboboreira. A Lavoura, $76: 16$.

LERENA, G.A., 1975. Cultivos de huerta. Buenos Aires, Editora Albatros, $601 \mathrm{p}$.

LOPEZ, C.E., 1961. Cultivo tarzado de melons (variedades (Charentais (y.) Ogen). Agricultura. Revista Agropecuária. $353: 494-499$.

MENDONÇA, F.A. \& E.F.C. VASCONCELOS, 1975. Estudo comparativo dos efeitos da poda e eliminação de flores e frutos de pepino. II: Comparação de 4 métodos. Revista de olexicultura. 15:84-87.

PASSOS, F.A. E E.F.E. de VANCONCELOS, 1975. Estudo comparativo dos efeitos de poda dos ramos e eliminação de flores e frutos de pepino. I: Comparação de 6 métodos. Revista de Olericultura. Botucatu, 15:81-87. 
PEDROSA, J.F. \& V.W.D. CASALI, 1982. Melhoramento genético do gênero cucurbita. Informe Agropecuário. 8:57-60.

PIMENTEL GOMES, F., 1973. Curso de estatística experimental. 5ạ ed. São Paulo, Livraria Nobel. 430 p.

PRADO, O.T., 1960. Espaçamento, adubação e poda de Cucurbitáceas. Hortalịças. Viçosa, 4:1-6.

RAMALHO, M.A.P., 1973. Hábito de florescimento e frutificação do pepino. Piracicaba, ESALQ/USP, 47 p. (Dissertação de Mestrado).

ROCHA, F.P.; I.G.C. dá SILVA \& E.K. MEYER, 1964. Tutoramento do tomateiro com e sem poda. Revista de Olericultura. $4: 141-145$.

ROBINSON, R.W.; H.M. MUNGER; T.W. WHITAKER \& G.W. BOHNI., 1976. Genes of the Cucurbitaceae. HORTScience Michigan, 11:554-567.

SARLI, A.E., 1958. Horticultura. Buenos Aires, Editorial ACME, S.A.C.J. 454 p. 
SIMS, W.L. \& B.L. GLEDHILL, 1968. Effects of plant size or mechanics clipping of pickling cucumbers. California Agricultural. $22: 4-5$.

SOARES, J.A. \& O.C. KOLLER, 1964. Estudo preliminar sobre sistemas de poda em tomateiro. Revista de olericultura. $4: 131-134$

SOARES, J.A. \& Q.C. KOLLER, 1965. Sistema de poda em tomateiro. Revista da Faculdade de Agronomia e Veterinäria. $7: 259-265$.

SOARLS, J.A.; O.C. KOLLER \& C.J. BARRADAS, 1976. Ensaio de condução de tomateiro do tipo salada. Revista da Faculdade de Agronomia da Universidade Federal do R.G. do Sul. 1:157-166.

SHIFRISS, O. 1947. Developmental reversal of dorninance in Cucurbita pepo. Proc. Amer. Soc. for Hort. Sci. $50: 330-46$

STEEL, R.G.D. \& J.R. TORRIE, 1960. Principles and procedures of statistics with special references to the biological sciences. New York. MC GRAW-HILI Book Co. INC. $481 \mathrm{p}$. 
TAMARO, D. 1942. Manual de horticultura. Barcelona Editora Gustavo Gili. 589 p.

VALIO, I.F.M., 1979. Auxinas. In: Fisiologia vegetal. 2ą ed. São Paulo, EPU - EDUSP da Universidade de São Paulo. p. 39-70.

WELLINGTON, R. 1956. The origin of the cultivated Cucurbita. America Naturalist. 90:171-176.

WHITAKER, T.W. \& G.N. DAVIS, 1962. Cucurbits: botany, cultivation and utilization. New York. Leonard Hill. $250 \mathrm{p}$.

WHITAKER, T.W. 1965. The origen of cultivated cucurbita. America Naturalist. $90: 171-176$. 
.47.

7. APÊNDICE 


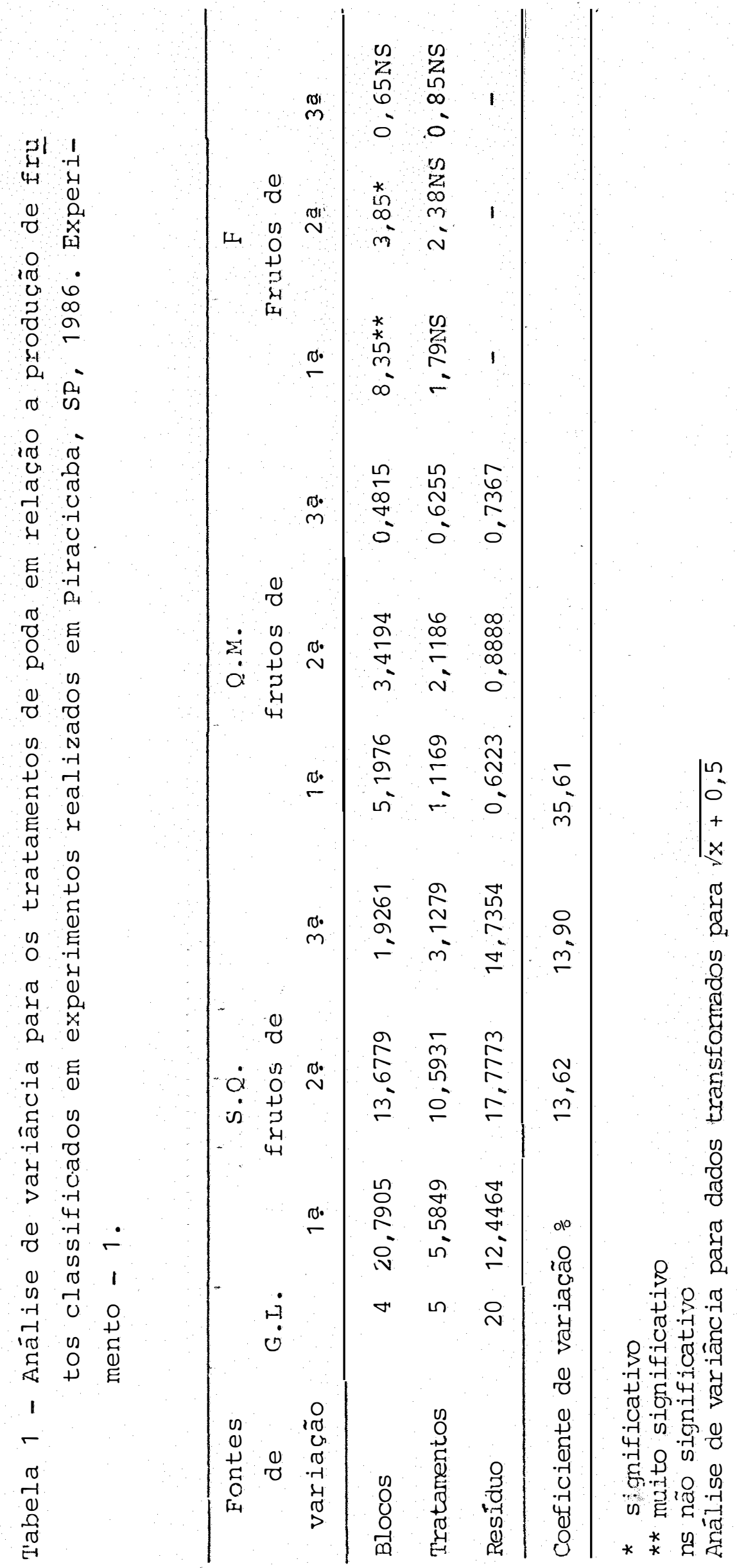




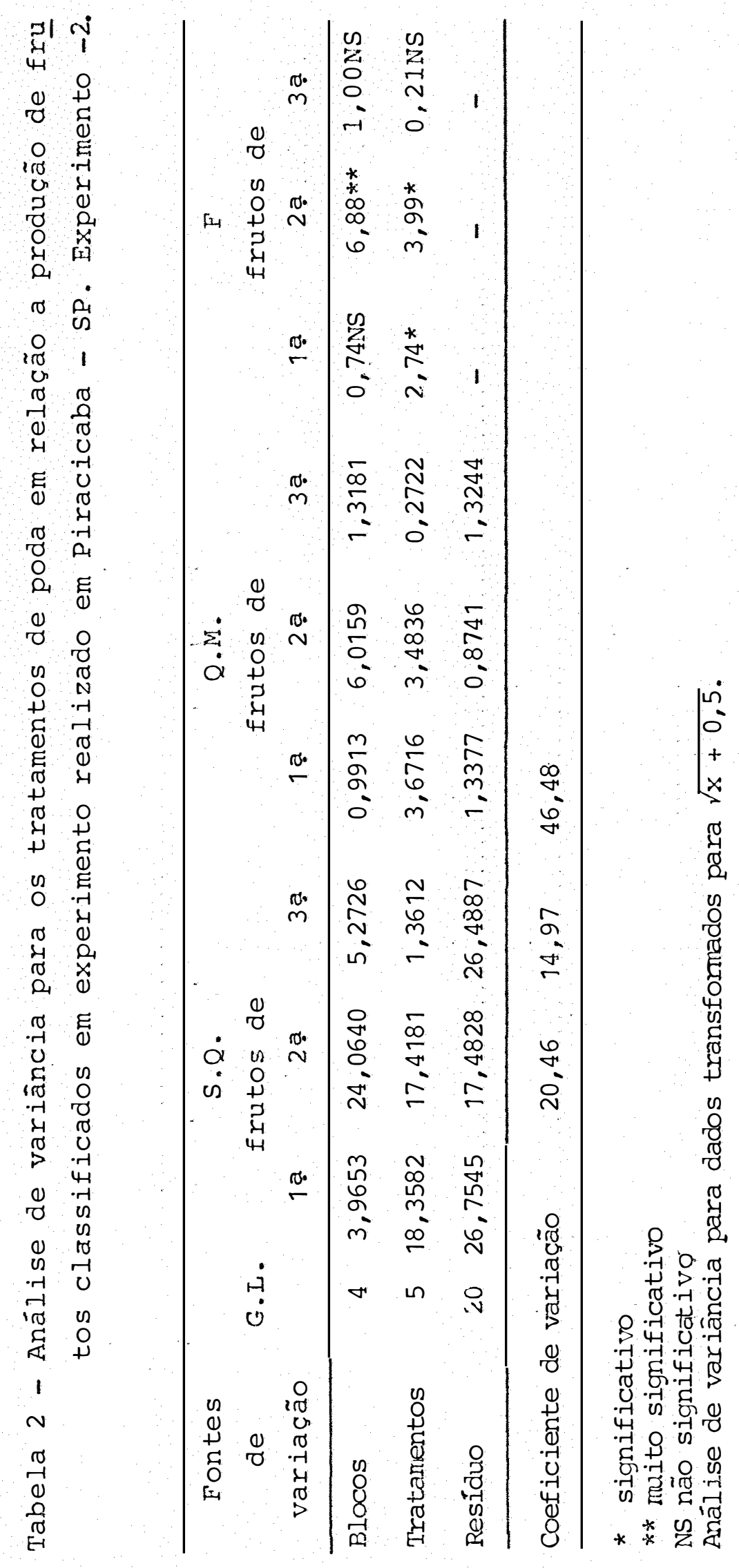

.49. 


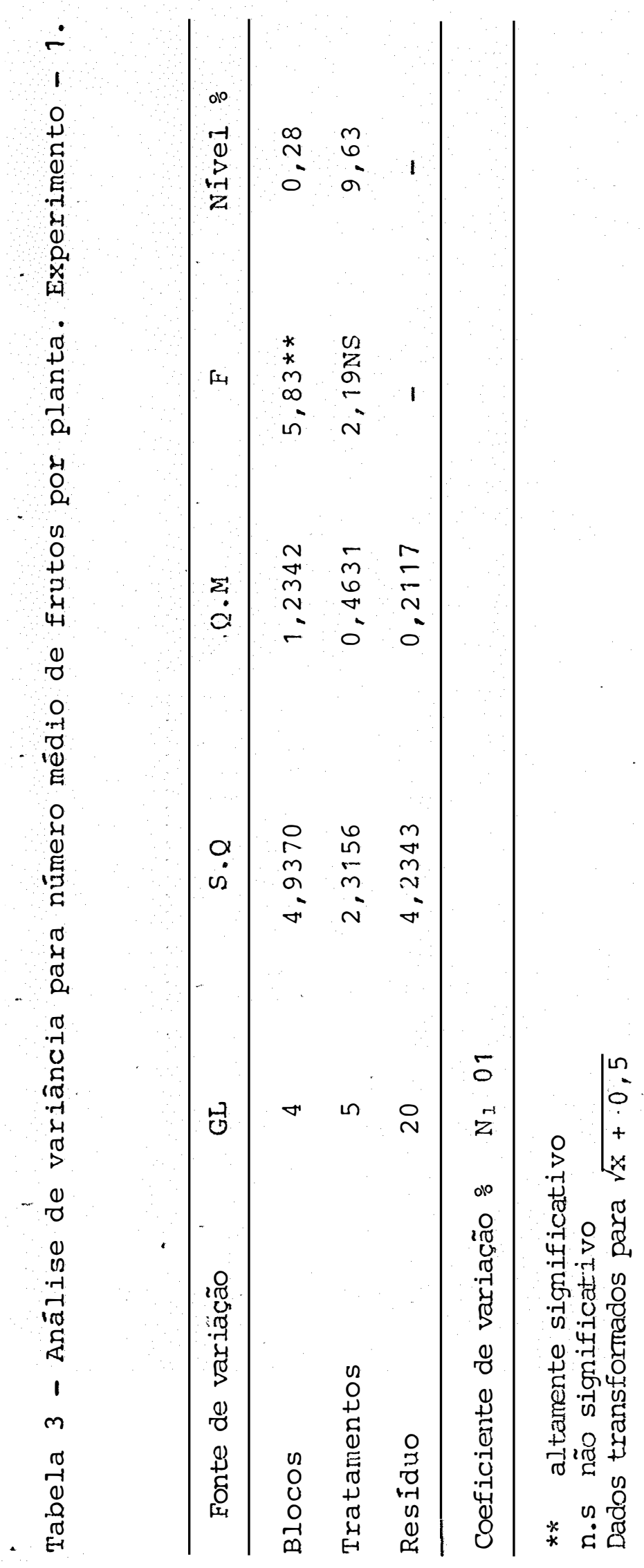




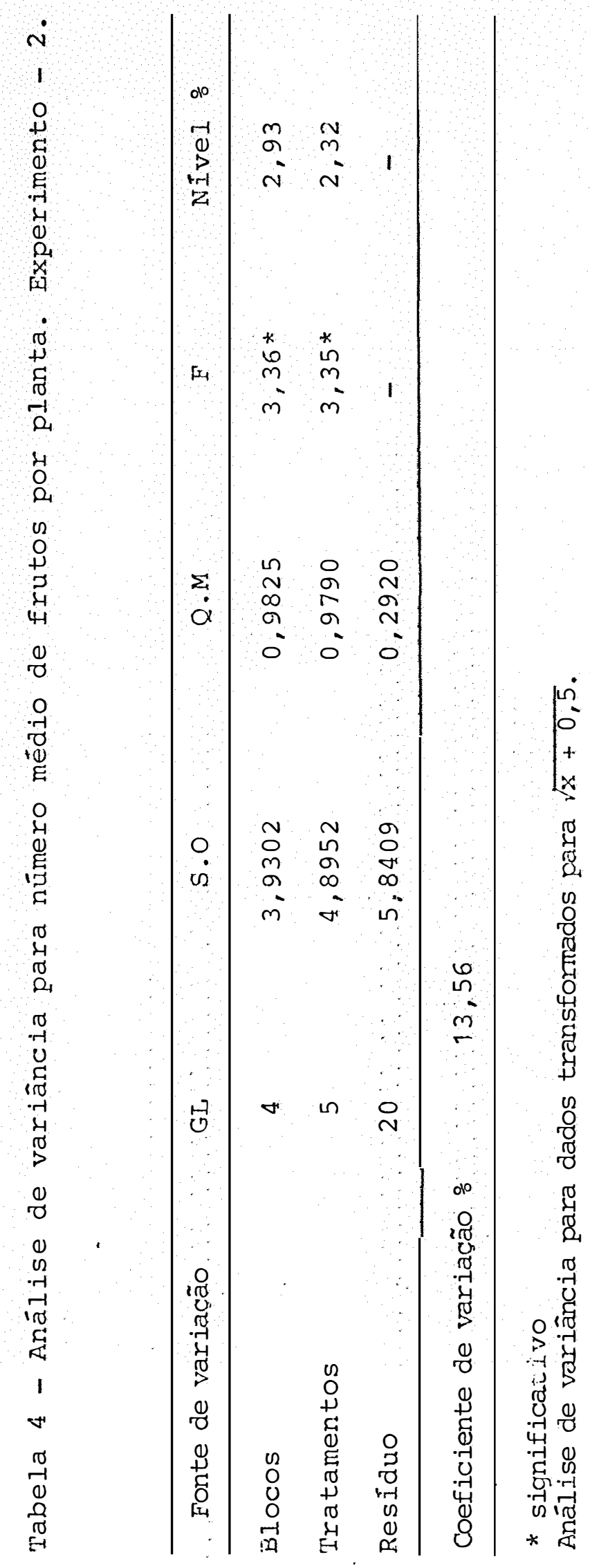

